Article

\title{
Government Programme as a Strategy-The Finnish Experience
}

\author{
Jan-Erik Johanson ${ }^{1, *,+}$, Elias Pekkola ${ }^{1,+}$ and Päivi Husman ${ }^{2,+}$ \\ 1 School of Management, University of Tampere, 33100 Tampere, Finland; elias.pekkola@uta.fi \\ 2 Finnish Institute of Occupational Health, PB 40, 00251 Helsinki, Finland; paivi.husman@ttl.fi \\ * Correspondence: jan-erik.johanson@uta.fi; Tel.: +358-50-318-5960 \\ + These authors contributed equally to this work.
}

Academic Editor: Aidan R. Vining

Received: 22 December 2016; Accepted: 18 May 2017; Published: 24 May 2017

\begin{abstract}
This article uses strategy metaphors consisting of a plan, a home and a game to study government programme formation in Finland. The strategy approach both contradicts and complements the traditional political science approach to government formation. The government programme has been strategic in the sense of separating the formulation and implementation parts of the strategy. The most important function of the metaphor of plan is to hold coalition parties together. The adopted austerity policy provides a meagre contribution to the expansion of services and the increase in government spending. Consequently, the home metaphor in the government programme appears in the distant future and in combating external threats. The game metaphor is apparent in the goal of making contracts with social partners. The vocabulary change from politics to strategy alters the government programme's position in terms of catering to the needs of civil servants, citizens and stakeholders. The strategy perspective might be instrumental in shifting open democratic debates to closed and secretive policy formations.
\end{abstract}

Keywords: strategy; government; policy; government programme

\section{Introduction}

Strategic management deals with the most important issues in society, which makes it a highly relevant perspective when defining and implementing goals within a government. Previous research has left a legacy of war and competition that has impeded the application of strategic thinking in the public sector context. Firstly, the origin of strategy in warfare lies in orienting the troops to defeat the enemy [1]. Secondly, the legacy of competition is connected with the management of large American companies in their attempt to adapt to the changing circumstances in the post-World War II era [2]. Both of these legacies are inherently alien to managing a government. Most often, there are neither external enemies to be defeated nor internal competitive markets creating rivalry between public agencies. However, strategy is about purpose, direction and goals; these are as important in public sector organisations as in private ones. The question is: Which purpose, what direction and whose goals are addressed? The answer, as always, depends on the observer's view of strategy.

There is a growing body of literature on public sector strategies [3-10]. More often than not, it tends to concentrate on the lower levels of government, policy issues, agencies and local government in particular. The nexus of political decision-making in government formation has not been on the agenda of strategic management thought. In our article, we ask a simple question: What is the role of the Finnish government programme as a strategy in its policy process, and how have its strategies been implemented so far? We are interested in the development of the Finnish government programme from the strategy and the policy process perspectives. We use strategy metaphors consisting of a plan, a home and a game and compare them with the basic political science concepts of policy and polity. 
Thus, we also reflect on the following question: What are we studying when we analyse a strategic government programme?

These latter two generic questions motivated us to write this article. What does it mean when a country adapts the vocabulary of strategic management at the highest possible level and in the most political document-the government programme? Should researchers also change their analytical tools to align with this vocabulary? Finland provides an excellent case example because of its comparably tightly coupled public administration, well-functioning and homogenous political system and multiparty majority government, leading to a situation where the government programme plays a truly significant role in shaping the political landscape.

The real-life developments in Europe and elsewhere encourage analysis of government formation as a research subject in its own right. The political turmoil following the financial crises of 2008 is one impetus for political instability, but the role of exogenous crisis has also unearthed existing latent divergences within political systems. In general, the rise of new right-wing or national populism with the defeats of left-wing parties has been instrumental in bringing about new instability in European politics. Coalition government formation has been problematic in Italy, Ireland, Spain and Belgium, not to mention the formation of a coalition government in predominantly majoritarian government systems, such as in the UK in 2010.

In Section 2, the conceptual analysis begins by discussing the strategic and the political framing of the government programme. In Section 3, the empirical analysis deals with the application of strategic management and political thought in the formation of the Finnish government programme. Section 4 assembles the different perspectives from strategic management and political science as applied to the changing nature of the government programme.

\section{Strategy and Policy as an Approach to the Study of the Government Programme}

Strategy language has been used for approximately two decades in Finnish public administration; however, the strategies have not been analysed from the perspective of either strategic management (forgetting the policy aspect) or policy (assuming that the strategy is only a trendy name for a policy). Empirically, the Finnish government and its ministries have started to refer to their policies in terms of strategy concepts. For this reason, we analyse strategy as a metaphor and ask how strategy can be understood in the language of politics. The structure of our presentation is following. First, we shortly present the strategy metaphors. Second, we discuss policy as a concepts and its relation to political and administrative dimension of public sector activities. Third, we provide our understanding of strategy as a policy process. In next chapter (3) we will describe the political history of Finnish government programmes followed by analysis of current strategic government programme through the strategy metaphors (3.1-3.3). In chapter four, we will conclude our analysis. In chapter five, we will provide some methodological limitations for the study.

Metaphors are not only linguistic expressions that equate concepts with other and often more ambiguous concepts-they are powerful tools for mapping existing ideas in a novel fashion [11]. Metaphors have been used in previous strategy research to map the strategy process [12,13]. Here, the plan, home and game metaphors aim to gather the theoretical perspectives of the research tradition into a limited number of concepts. First, the metaphor of planning covers the most prominent aspect of strategic thought in trying to prepare for the future that is yet to come, often with projections and measurements [14]. Second, strategy as a home deals with the literature on the human side of the strategy, which appears, for instance, in strategic human resource management [15] or leadership ideas promoting the charismatic aspect of strategy [16]. Third, the game metaphor refers to managers' talent and cunning in manoeuvring to fulfil their organisations' goals; game theory is a formal expression of such an idea [17].

This distinction into three strategy metaphors is based on theoretical developments into three main sources of strategy in the business context: (1) industrial organisation economics; (2) the theory of firm growth; and (3) leadership studies [18] rather than on the discursive or practice approach in 
strategic thought. First, industrial organisation economics puts forward a deliberate rational idea of planning within industries. Second, the metaphor of game is present in the theory of the growth of the firms in orchestrating the resources into new fruitful combinations. The image is that of a child's play in the constant rearrangement of blocks into new constellations to imitate real developments rather than building on 'savage' fantasies of unassisted imagination [19] (p. 63). Further, the image of game is present in industrial organisation economics as a game of power in gaining a dominant position in the industry as well as an independent aspect in the game's theoretical formulation [17]. Third, the leadership qualities sought in the human resources approach have a direct link to the metaphor of home in producing secure and meaningful social environments.

Strategy has numerous interlinks with the term policy. Similar to strategy, policy has multiple meanings. It is a label of a field of activity, an expression of a desired state of affairs, a proposal, a government decision, a formal authorisation, a programme, an output and an outcome and a process (e.g., [20]). Recently, De Vries [21] created an inventory of how policy has been defined in the classical texts of public administration, proposing that public policy can mean what governments choose to do and not do [22], an authoritative allocation of values [23], facing the problems of the public [24], the government's actions [25] or the integration of the government's and other stakeholders' views [26]. However, De Vries proposes analysing public policy through the entire policy cycle, leaving us without a definition because it includes every single activity done in the public system. Another way of creating a definition is to approach it from the angle of normal language. According to the Oxford Dictionary [27], synonyms for government policy include 'plan, strategy, proposed action, blueprint, approach, scheme, stratagem, program, schedule, code, system, guideline, intention, notion, theory, line, position, stance and attitude'. An online thesaurus [28] proposes 'disorganisation' as an antonym for government policy, while Parsons [29] suggests 'aimlessness'. If we adopt a positive way of defining policy concept, it is something that organises and provides an aim for action.

These links between the terminology of policy analysis and strategy research are evident in everyday discussions. Policies are formed similarly to strategies, using the strengths, weaknesses, opportunities and threats (SWOT) analysis in addition to other techniques. Policy documents are called strategies, and they are put into action. Thus, is there any difference between these two processes and practices?

Fredrickson et al. [30] make a clear distinction between policy and administration. With policy, they refer to goal setting and visions in the public sector (politics), and with administration, they refer to implementation and management (bureaucracy). This is one traditional way of defining policy. If we make a clear distinction between politics and administration, the strategy can be thought of as a tool, a process or a document provided by the administrative (managerial) public office holders and the policy guidelines for administrators (managers). A founding father, Woodrow Wilson of American administrative science, put this as follows:

Politics is thus the special province of the statesman, administration of the technical official. "Policy does nothing without the aid of administration"; but administration is not therefore politics ... [T] his discrimination between administration and politics is now, happily, too obvious to need further discussion. [31] (pp. 210-211)

If we take a more continental approach, which regards public administration as part of the public entity or the state, we are doomed to this exact discussion (see [32]). Pierre expresses it as follows: ([33], cited in [34] (p. 143)):

$[O] n$ the other hand we see policy-makers using administrative reform to displace accountability from public policy; on the other hand, we see the very same policy-makers trying to increase their control over bureaucracy. Whilst this appears to be two inconsistent developments, they may in fact reflect a general desire among elected politicians to increase their influence over bureaucracy while at the same time avoiding responsibility for the actions of the bureaucrats. 
This simple dichotomy is rhetorically problematic-the 'strategy' as a concept is part of the management vocabulary; it naturally falls under the context of public management that is evidently part of administration, not policymaking. In our empirical setting, the government's programme (the most political and aim-providing document) is called a strategy, so does it imply that policymaking has become management? Answering this question seems easy at first glance-it is evident that policy and strategy are two distinct concepts and have quite different meanings. However, when a government starts to call its political programme and implementation plan a strategy, it prompts several fundamental questions. Fundamental questions have no fundamental answers; however, we can draw on some dimensions to address the challenge of responding to the question. The difference between the policy and the strategy processes can be approached from at least three perspectives: contextual, teleological and processual.

(1) Contextual. The organisational and resource environment is fundamentally different (legally, ontologically or financially) in the public and private sectors. This means that in the public sector, there are no strategies (in the same sense as in the private sector), but instead there are policies that are called strategies. If we take this as a starting point, we end up discussing the differences between public and private realms of management (see [34]).

(2) Teleological. We can distinguish the strategy from the policy process based on the aimed for outcome. Consequently, all future-oriented processes (regardless of the wording and the techniques) aiming for the public good are policies, while future-oriented processes aiming for profit are strategies. This means that the public sector might have strategies, but only in publicly owned companies and other public agencies with a profit motive. This can be connected to the discussions on public value [35] and values [36].

(3) Processual. We can distinguish the strategy from the policy process by assuming that the process itself is somehow different (see [37,38]. Here, we might have two different positions:

a. Rhetoric. We can assume that if the strategy language is used, we will find that strategies (i.e., what are called strategies) should be approached as such regardless of the sector.

b. Realistic. We can assume that if the future-oriented process is operated with techniques, tools and steps peculiar to the public (regulatory) process, it is a strategy.

This leads to another interesting discussion on the differences between policy and polity. Polity is loosely defined in political science. For instance, according to the definition in Andrew Heywood's prominent textbook Politics [39], 'polity is a system of social organisation centred on the machinery of government' (p. 5), while the policy concept is narrowly defined as an 'output of politics' (p. 400). However, the connection between policy and polity is crucial for this discussion on public strategy because strategy incorporates aspects of both concepts. Especially when the government programme is taken as an example, which is at the core of polity, it is as political as a document can be and still provides a direction for the administration, is partly prepared by the administration, is used to limit the administration's power and is called strategic.

A conceptual distinction between policy and polity provides a good framework for analysing the changes in government programme formulation and the implementation process, that is, the duality of political (providing the aim) and administrative (organising) steering in the strategy process. According to this thinking, policy refers to the regulating or goal-setting aspects of politics; it is formed by politicking, that is, acting or behaving politically. Polity refers to a political space or arena that is needed for policymaking [40].

Polity is actively shaped and reformulated by politicising issues to be operational and debatable in the political arena. The active process of politicking and politicising during government programme negotiations is often neglected, and the programme is studied as a neutral steering document. Policy has a teleological connotation, an orientation as a route map of activities toward a selected, admirable possible future [41]. Paradoxically, the government programme as a policy is the mechanism to enable 
change, but it is also a way to create continuity in relation to prior government programmes and to parliamentarian decision making.

\section{Government Programmes in Strategic and Political Contexts}

The previous research on government formation has identified the following aspects that influence the process: exogenous contextual factors, resource distribution among political actors, politicians' preferences, institutions and critical events. In an attempt to amalgamate these aspects into a single theoretical framework, there is an idea that bargaining requirements comprise two main aspects (1) agreements with other parties; and (2) the practice of pleasing voters [42].

The current Finnish government was appointed at the end of May 2015, and the government programme was published at the same time. The government comprises three parties: the Centre Party (Suomen keskusta, established in 1906), the Conservative Party (Kansallinen Kokoomus, established in 1918) and the Finns Party (Perussuomalaiset, established in 1995). Traditionally, the Centre Party has enjoyed support from rural areas. The Conservative Party gains support from the major cities, professionals and the rich. The Finns Party is a populist party, which typically gathers support from those classed as middle-income and people with lower educational attainment. The Finnish political system contains a strong corporatist element, which emphasises the need for negotiations with social partners, as witnessed in other Nordic countries [43].

Recent political practices in Western and Eastern Europe from 1990-2012 show that the most basic types of governments include (1) single-party majority government, (2) minimal-winning coalition government (where there are multiple parties in government and the support of every single party is required to maintain a parliamentary majority), (3) surplus coalition government (where there are multiple parties in government but the support of all parties is not needed to maintain a parliamentary majority), (4) single-party minority government (where there is only one party in government without a parliamentary majority), and (5) coalition minority government (in which multiple parties do not control a parliamentary majority) [44]. The current Finnish government is a minimal winning coalition (Centre party with 49 seats, True Finns with 38 and a coalition party with 37 seats out of the 200 total seats in parliament). As all the parties are needed to progress government policies, there is a pressure to cater to the political aspirations of all parties equally.

The political nexus lies in the cabinet and the ministries, which are the agencies responsible for administrative implementation. In the 1990s, ministries and central agencies shared responsibilities in the division of labour within the central government, but administrative changes meant that the ministries and the ministers became the primary operators in the formation of the government agenda. The problem with this development was that it weakened the role of the cabinet as the collegial decision-making body steering the ministries. Strengthening of the cabinet has been sought in a number of reform projects via allocating a workforce, research funds and expert knowledge for the cabinet's use. Many of these reform projects are related to preparing the government programme.

Since its independence in 1917, Finland has been under 73 governments. Until the 1980s, the presidential political system and the political culture produced short-term governments, typically serving for only a year or two. Beginning in the 1980s, the parliamentarian tradition of the Finnish political system gained strength, and the terms of governments conformed to the terms of parliaments. In the interim, the status of the prime minister and the role of the parliament became stronger with the reform of the Finnish constitution in 1999; this was at the expense of the president, who was charged with handling foreign relations (excluding the European Union (EU)) and conducting mostly ceremonial duties in internal (and EU) politics.

The programmes of the early post-independence governments were published in newspapers, and they were only a few pages long, consisting of political declarations with varying levels of political visions or details of action. In the late 1980s, the government programme for a four-year term (1983-1987) was still only a few pages long-it simply indicated the main political aims in the major political sectors. From the 1990s onward, the programmes gained length, term by term, with the 
previous government's programme being 79 pages long and containing a detailed action plan for the ministries. In the multiparty setting, the government programme is inherently a compromise among the parties representing different constituencies and political ideologies. The government document has become more binding in the sense that new policies cannot be taken up in the government agenda if they are not already included in it. In this regard, the government programme serves as an instrument to restrict the tendency to overspend common resources in multiparty governments [45]. Further, in this setting, ministers from different parties have an incentive to increase their own budgets to gain political credit for their own party, although this easily leads to excessive spending, which is not desired by the government coalition as a whole [45]. Needless to say, the binding nature of the programme makes it very difficult to tackle any sudden political change.

The development of the government programme from the cabinet's declaration to the administrative-political agenda can be described as 'organic'. The document and the process are regulated with only a few general guiding principles. According to the Finnish constitution, 'the groups represented in the Parliament negotiate on the political program and composition of the Government before the Prime Minister is elected' (Section 61). When the government has been formed, '[t]he Government shall without delay submit its program to the Parliament in the form of a statement' (Section 62).

In the prime minister's office, the development of the government programme has been perceived as a challenge for the strategic management of the Finnish central government. According to the reform proposals, the government programme should comprise a short list of the 3-5 most important policy goals of the new government. In addition to the main aims, the government should, in close collaboration with the ministries, provide a government action plan with a more detailed description of the policy goals and the resources used to achieve these goals. This new document should combine the current two distinct processes of setting the political agenda and the budget framework. The time frame for the new government programme is longer than before. The more detailed action plan was prepared after the government programme by gathering expert knowledge to evaluate changes in the environment and to set targets in a more informed manner.

The current Finnish government reached an agreement on the government programme at the end of May 2015. It was described as strategic because it followed the structure of a typical strategy document in identifying strengths (e.g., strong and functional democracy, capacity to invent), weaknesses (e.g., rigid structures, bureaucracy), opportunities (e.g., agile country, free trade) and threats (e.g., international security, lack of European competitiveness). It contains long-term (10-year) goals as well as goals to be attained during the electoral term. The document is 34 pages long, and it includes a 36-page appendix.

The current government programme contains five key strategic areas: (1) strengthening employment and competitiveness; (2) renewing knowledge and education; (3) improving health and well-being; (4) speeding up biotechnology and 'cleantech' solutions; and (5) reforming procedures through digitalisation, experimentation and deregulation. The government programme also includes social and health reform, the aim to find a solution (with social partners) to increase the Finnish economy's competitiveness by $5 \%$ (social contract, later called a 'competitiveness contract'), decreasing the responsibilities of local governments, and reorganising regional authorities. Most of these areas have a 10-year target, a target for the electoral term, ideas about how to measure the targets and identified spearhead programmes for the specific strategy areas. The measurement of the targets is very limited; in many cases, it is stated that the indicators for the targets will be developed later.

These goals are operationalised in 27 strategic priority projects, which are further divided into a number of subtasks. Additionally, the government programme includes guidelines for financial and fiscal policies; structural reforms; EU policy; foreign, security and defence policies; and justice, internal and immigration policies. 


\subsection{Strategy as a Plan}

'The government now has a common solution on the whole package and the historic reform will finally happen' (PM Sipilä and party chairman of the centre party on social and health reform, 21 December 2016, Reuters). The government programme states 'The Government will implement the decisions in accordance with its plan', [46] (p. 13).

The strategy discussion emphasises the foresight acquired through planning. In the public sphere, the analytical policy approach also illustrates the planning tradition of trying to divide government actions into tangible areas and specific programmes, such as industrial, economic and social policies.

In steering the central government, the planning, programming and budgeting ideas developed in the US in the 1960s gained some interest in other developed countries as well [47]. In the Finnish context, the rigidity and slowness of the central planning did not provide a good platform to develop goals for changing circumstances, which included governments serving less than their electoral terms. In a somewhat similar vein, the Finnish government employed policy programmes aimed at reaching broader-than-ministerial targets, such as employment, entrepreneurship, knowledge society and participation of citizens in the 2000s; however, the lack of funding for these programmes and the coordinating problems with the budget cycle hindered their successful implementation [48].

The current government programme aims to balance the $€ 10$ billion long-term deficit of public finances by the 2030s. The measures to attain these goals include employment and economic growth ( $€ 1.5$ billion), cutbacks and structural changes ( $€ 4.5$ billion), social and health reform and efficiency increase ( $€ 3$ billion) and reduction of local government responsibilities ( $€ 1$ billion). The stated 10-year targets, such as the beneficial characteristic of paid labour in contrast to social benefits, the motivation for continuous learning and balancing public expenditures are brave and worthwhile targets, but the measurement problems are obvious. Long-term targets are problematic since no one can guarantee that these will remain on the agenda of subsequent governments.

The social and health reform is a prime example of the appearance of and problems with planning. The document contains three steps, consisting of the integration of social and health services, the unification of financing these services and the increased options for choice and role for the private sector in providing public services. There is a widespread agreement on the need for change, but discrepant stakeholder interests cannot easily be combined. The actual reform has been under preparation by two previous governments, but they have been unable to solve the political problems included in it. The main controversy deals with the local government authority and government intervention. Local governments are responsible for social and health services, but the number of local governments (317) and their unequal sizes make the system extremely decentralised. Previous attempts to amalgamate local governments in a voluntary fashion have been very slow. Direct government intervention to force local governments to form larger units or to reorganise social and health services has encountered local government opposition, backed by the strong constitutional guarantee of local government autonomy. The current government aims to reduce the number of social and health providers to no more than 19 units, which would include democratically elected councils for the units.

In terms of planning, the government programme has a sharp discrepancy between the past and the future. In its strategy document, the government takes a strong stance on the distant future, many times until the 2030s, but there is very little description of the past efforts of previous governments or the history of Finnish society. Of course, this is how standard strategy documents are written, but in the political sphere, it gives a clear signal for change and is against continuity with the past. The implementation phase has proven to be complicated, but the process also witnessed unforeseen developments [49] when the conservative party changed its party chairmen due to perceived lack of party interest in the adopted social and health care model.

From the policy perspective, strategy as a plan neglects the politicking and politicising aspects within the government. Planning is a rational process, providing policy as an outcome that can be achieved without politicising and politicking. For the last few terms, the ministries have done a lot of planning prior to the programme negotiations. During the preparation of the current government 
programme, the ministries faced a new situation in which their plans were not taken as starting points, and the negotiations had a new political atmosphere where the politicians were the main players in strategy formulation. This creates a paradox in a corporatist society such as Finland; when planning is made more political (by the government coalition), the other stakeholders of society (such as labour market parties) are excluded from the discussion. Thus, in a sense, the politically managed planning process is more apolitical (managerial) than the bureaucratic policy formulation and planning.

\subsection{Strategy as a Home}

'Norway has oil and NATO, Iceland has fish and NATO and Finland has the EU. Without it, we would be economically weaker and have less security' (Former Minister of Finance and party chairman of conservative party Alexander Stubb, quotehd.com).

Strategy relates to the goals of the organisations. Strategies offer hope for a better future when all hope is abandoned. Therefore, strategies enable survival under the conditions in which the future seems bleak. The following extract illustrates this point:

The young lieutenant of a small Hungarian detachment in the Alps sent a reconnaissance unit into the icy wilderness. It began to snow immediately, snowed for two days and the unit did not return. The lieutenant suffered, fearing that he [had] sent his own people to death, but on the third day the unit came back. Where had they been? How had they made their way? Yes, they said, we considered ourselves lost and waited for the end. Then one of us found a map in his pocket. That calmed us down. We pitched camp, lasted the snowstorm, and then with the map we discovered our bearings. And here we are. The lieutenant borrowed this remarkable map and had a good look at it. He discovered to his astonishment that it was not a map of the Alps, but a map of the Pyrenees. [50] (p. 54)

The lesson of this excerpt is that in many cases, the power of strategy cannot be found in its accuracy or level of detail but in its ability to give guidance and comfort in ambiguous situations. Moreover, the genuine belief in the strategy enables the concentration of effort even if the belief eventually proves to be faulty.

For the managers, strategies provide clarity in confronting ambiguous environments. In this sense, strategy in itself is a human-made artefact created for the psychological security of the managers. Strategy serves as a boundary object for the top management to handle the fundamentally unpredictable nature of the environment. Strategy is a manager's cuddly toy or teddy bear, but even false security could be better than confronting insecurity in its full force. The same applies to the audiences of the top decision makers. Charismatic leaders are able to convey the message of purpose, security and positive future prospects to their followers [51].

Strategy as a home relates to the limitations of human's information-processing ability [52]. Strategy enables us to identify our basic needs in a simplified form. In this sense, strategy comes close to one of the ideals of theory building, as it offers insights into the basic features of our environment without being entangled in the minute details of our existence. In democratic political systems, decision makers working under the mandate of their constituencies and appointed officials offer the basic ingredients of a home where we feel comfortable living. Within administrative processes, the limitations of human information processing lead to incremental decision-making in which past actions are used as an anchor point [53], to muddle through administrative problems [54] and to collect options for problem solving, in other words, 'garbage can decision-making' [55].

The government programme gives some hope for a brighter future. The title of the document is 'The solutions of Finland', and the vision of the strategy is 'Finland 2025-build together'. In the situational analysis, Finland is described as safe, innovative, economically sustainable and part of Europe. Commentators have been quick to identify the strategy language in which the lack of appearance means the lack of attention. There has been the critique that the government does not espouse equality and solidarity because they are not stated as goals in the government programme. 
It is also noteworthy that 'welfare society' appears as an area of strength but not as a subject to be developed. Within the government programme, the aspect of the comfort and security of home comes from different sources other than the advancement of a welfare society. The sacrifices made by the citizens through cutbacks and tax increases guarantee the continuity of their existing well-being and relative prosperity in the future. The government programme states 'The Finnish people are ready to accept even difficult decisions, if they are implemented in a fair manner with an eye to a better future', [46] (p. 8). The security of home itself appears in the aims to anticipate and solve external and internal security threats. The worsening of the international security situation and the consequences of the Ukrainian crisis emphasise the importance of the EU as a provider of security, together with other international organisations. The United Nations, the North Atlantic Treaty Organization and the Organization for Security and Co-operation in Europe are perceived as forming the backbone of international cooperation in international security.

From the political perspective, home represents an apolitical polity-a space that is stable, safe and secure. Within its limits, all questions can be solved in an appropriate manner, and political issues are raised in the agenda as part of the system and its decision-making machinery. Thus, the people can trust that professional members of parliament, ministers and public administrators are managing their common issues. The home metaphor emphasises the citizen not as an active member of society but as a family member, following the rules and discipline of the family and its head. In the area of policy, the government programme states that Finland is and will be a caring society based on trust and respect, but contrary to this general statement, most of the numerical data in the document indicate a sharp decrease in the most important areas of public spending, such as education or social and health services.

Here, the government programme's strategic emphasis has created a situation in which the government, and especially the prime minister, personally hold a position of trust in securing the polity. This is a new situation in Finland, where the public has laid its trust in the law, bureaucracy and the public as an entity. The strategic approach in the government programme formulation has shifted politicising and politicking from the planning and formulation phase to the implementation phase, while the government programme formulation has become a more clandestine process.

\subsection{Strategy as a Game}

'Truth is the strongest force' (Foreign Minister Timo Soini and party chairman of the Finns party on the Greek debt crisis, 11 August 2015, Euronews).

It is often the case that strategy is depicted with the game metaphor. In a game, it is possible to anticipate the opponent's moves, and the basic ingredient of the game is that an opponent exists. The game of chess serves to illustrate this point. The pieces have a limited but considerable number of possibilities of movement on the board, and a full command of the game requires a substantial understanding of the sequence of different moves. The galloping of the horse and the movement of the bishop are fairly uncomplicated, whereas en passant and the castling are more complicated procedures. The struggles among political parties to advance the interests of their respective constituencies and the rivalries among agencies regarding the limited budget appropriations are illustrations of gaming in the public context [56]. In games, there are winners and losers. The advancement of a contender's own position in the political combat is a zero-sum game in which the strong players conquer and the weak players surrender. A player's cunning may take many forms-sometimes, hiding one's own goals and the ability to divide the opposing forces can be instrumental in reaching the intended future. In game theory, there is an interesting unresolved question of alliance formation, as the relevance of power resources in alliance formation has yet to be solved [17]. More generally, within the language of politics, a reference to a game prompts questions of power, but games can also be just games-joyful exercises of leisurely activities.

The game metaphor is a relevant part of the intercourse between strategic and political analyses. The language of strategy in the discipline of politics relates to the opportunistic calculating behaviour 
of the political actors as opposed to the advancement of the ideologies of the political movements. In this sense, strategy is an apolitical aspect of politics. On the other hand, the foundation of strategic thinking in managing business corporations is a penetration of economic thought into the business of politics.

Politics and administration include a pure contest for power, but the logic of the game contains rules that produce decent behaviour. Following the institutional argument, the rule-bound behaviour created by political institutions simplifies and offers continuity in political decision making [57]. In the globalised world, the boards in the game are undergoing changes, and the alliances do not conform to the traditional lines of geographic spheres. In other words, new and unanticipated alliances might offer joint and mutual gains for the parties involved. Most importantly, alliances and cooperation may well produce overall stability and order even though the environment is more exposed to change.

Regarding the relationship between politics and administration, some closure within the administration-politics dichotomy was reached by the 1980s when a pure hybrid model of government was put forward. Politics and administration were becoming hybridised, which meant there would be no need to separate political decision making from the formulation and implementation of goals [58]. Discussion of the division between politics and administration has not faded away [59] —even if we accepted a hybrid government, it would be problematic for politicians' accountability if administrators became responsible for decision making. Sometimes there is a genuine need to separate politicians and administrators, but we could equally see administrators as being responsive to citizens or autonomous in their administrative practice [60].

The game frame is an integral part of the Finnish government programme, as it contains conditional austerity measures worth $€ 1.5$ billion in case the competitiveness contract with the social partners (employer and employee peak organisations) fails. According to the government programme 'the Government will make a proposal to social partners on measures (social contract) to reduce unit labour costs by at least 5\%' [46] (p. 14). In the case of failure, the conditional austerity measures include both cutbacks (in pension and unemployment benefits and child benefits) and tax increases (income tax increase and reduced tax relief on housing loans). In the spirit of the game, the government programme sets the stakes for the process. The complication in terms of the game metaphor is that the cutbacks and the tax increases targeted the population at large, whereas the social partners deal primarily with the issues related to those in the workforce [61]. In such a setting, employees faced a certain deterioration of their working conditions in terms of salary or work hours (due to the agreement with the government), but the cost of the conditional austerity measures was spread across the larger population. Consequently, the incentives to reach an agreement with the employers and the government were not particularly strong. Nonetheless, the centralised agreement with labour market partners was reached in the summer of 2016.

From the perspective of politics, the game brings action to the government programme. The game is all about politicking and politicising. The problem with the metaphor is that by using it, the 'meta game' might be easily lost. In politics, the rules, teams and arena comprising the polity can be altered. Politicising the game and not just moving, but also creating new goalposts, are important parts of the programme. The developments in the competitiveness contract have altered the way that the government deals with its social partners; it involves not only negotiation, but also the use of the government's sovereign power in compelling constituencies to comply with the government's goals.

\section{Discussion}

The results of the developments in a government formation of a single country cannot be generalised to the practices of governments in other countries. However, we have put forward the idea that discussing strategic management extends the simple emphasis on strategic planning, and that applying strategic management can be used to guide the government formation process. We use the formation of the Finnish government as a case example of such a procedure. The analysis gives insight into the previous discussion of government formation. First, the strategic orientation puts politics 
ahead of the allocation of resources; it might create new lines of demarcation between politicians and bureaucrats and offer new ways to inform the electorate. With the help of strategy metaphors for plan, home and game, it was possible to specify government policy targets and bargaining strategies. Within the multiparty setting, the most important function of strategy as a plan is to secure continued alliances among the political parties forming the government. The audience for the home is the electorate-the voting public that needs to be convinced of the righteousness of the selected policy tools. The explicit audience for gaming comprises the social partners that are required to comply with the government's demands. The implicit audience of the game can be found in the left-wing parties connected to the employee side of the social partners.

The theoretical shortcomings of the strategy as a plan are already well documented [14]; nonetheless, the separation of the design from the implementation of the strategy makes perfect sense in the political-administrative system. It is for the politicians to formulate the overall guidelines for the future, which are then implemented by civil servants. The problem with the separation of politics from administration is partly temporal and partly relational. First, the four-year government term is very short to incorporate many strategic stages, which means that there is a very limited time frame for experimenting with and assessing the benefits of feasible options. Second, the separation of the design from the implementation builds a barrier between politicians and bureaucrats. The programme can be communicated to civil servants only after its completion, which requires extensive interaction between politicians and bureaucrats. In the case at hand, the evident hurdle for lively social intercourse was the change in the external environment, which diverted politicians' attention away from the implementation of the programme. In a more speculative tone, the separation of the strategic stages might in itself hinder successful implementation, as those responsible for concrete actions have been unable to assess the feasibility of the formulated goals. The current strategy does not give administrators a strong role in the political part of the programme formation, but it instead emphasises their role in implementing it. As for the stakeholders, the government programme formation has shut them out of agenda formation.

In everyday language, the basic definitions of strategy and policy are surprisingly similar. One of the main differences seems to be the openness of the process. In both the strategy and policy literature, formulation and implementation are separated; this separation is questioned and criticised for being too simplistic $[14,62]$. In both the policy and strategy literature, the audiences are many, and the ways that they are conceptualised are different (stakeholders vs constituencies). If we take the metaphoric approach to the government programme as a strategy, we can perceive that it functions as a plan, a home and a game. These metaphors are also connected to different functions of the state. Strategy is a policy plan for overcoming challenges and is designed for the administrators implementing the strategy. It is a home that provides safety and the continuity of hope for citizens in the midst of turbulent times. Additionally, it is a playground for parties and corporations to set up games. It seems that the wording of the government programme also has an impact on the process, which can be observed in the perceptions of the context, the telos and the process of the government programme. The end outcome of the strategic efforts with the government programme cannot be estimated at present because the four-year government cycle is currently only halfway complete. However, it seems that the strategic government programme is shifting the Finnish legalist-corporatist society in a more parliamentarian-managerial direction. We can already see that there are changes in the telos of government (i.e., state property is seen as part of a balance sheet and not as collective capital). However, the contextual differences in the operational environment are still major, so the discussion on differences in public and private management will continue. However, the processual rhetoric has changed, which might lead to realistic changes as well. It is probable that research will support this transformation by adopting the same vocabulary and concepts as those that the practitioners use.

It is evident that the government programme has many simultaneous functions, making it easy to view through the strategy metaphors of a plan, a home and a game. The government programme aims to provide directions and predictability about the prosperous future of the nation (plan). Tentatively, 
slow economic growth, combined with government cutbacks, is not the most viable occasion for planning, which in essence aims at bringing about some bright future conditions rather than adapting to a seemingly deteriorating environment. The government programme aims to secure the well-being and safety of the citizens (home) by opposing external threats or putting forward domestic improvements, but it is also a device to set the game. By doing so, it aims to provide the rules of the game (i.e., the possible moves and the number of players) and to set the priorities for a successful game.

The basic ingredients of strategy as a home include security and comfort. The political controversies related to the extensive social and health reform have raised concerns about the government's ability to make decisions. The situation is worsened by the fact that a coalition government is based on the mutual adjustment of parties rather than on the charismatic leadership of any particular person. As social and health reform has not yet been implemented, the benefits for citizens' well-being remain to be seen. The main aspect of strategy as a home has appeared in opposing external threats. The seminal example has been the handling of the refugee crisis confronting European countries due to the unrest in the Middle East. First, the government has been able to find accommodation for the immigrants without creating too much domestic turmoil. Second, the combined action of European countries has eased the fear of the further influx of immigrants.

The game metaphor best suits the stereotypical image of politics as manoeuvring among different and often mutually conflicting interests. Moreover, an important aspect of the game is that there are winners and losers. The most obvious case of gaming has been the government-induced negotiations with labour market partners on the social or competitiveness contract. The carrot-and-stick strategy adopted by the government, as laid down in the government programme, has proven efficient in reaching agreements. The resulting labour market contract has been detrimental for employees and has shifted some of the financial burden from employers to employees. The government's role is to buffer some of the costs shouldered by the employees through tax reliefs and withdrawing further cuts in the government budget. The social contract is definitely a victory for the government and a concrete example of the practical implementation of the government programme.

When reading the strategic government programme, the contextual dimension is not much emphasised and subsequently, the use of strategy language is not questioned. From processual perspective strategic government programme is rhetorically a strategy as we can see the strategy metaphors can be applied to it like into any other strategy document. It is also a "real" strategy because techniques like swot and closed management discussions, peculiar to Finnish political culture, has been used to formulate it. From teleological perspective, the government programme is still mostly written in policy context and the goals are written as aiming for value for general public not to strengthen the "state-corporation". However, there are some exceptions like the minor change in practises e.g., in the collective ownership the former "national wealth" is seen more as "balance sheet", and in competitiveness in which one of the main aims of government is to make the ownership and investment more profitable in Finland.

The assessment of the government programme opens up several future research themes. First, the strategy language can change the role of citizen to an "employee" or a "customer" not a constituting actor in the politics. This takes us back to the basic question is the government programme as a managerial document or a frame for political agenda. Second, a parallel avenue that we would like to follow in future is the role of different audiences for the government programme i.e., for whom it is actually written. Third, the long-term implementation of the programme gives a possibility to track the temporal aspect of strategy formation. It will be interesting to observe whether the change in the government programme leads to corresponding changes in the actual implementation.

\section{Materials and Methods}

This article is based on publicly available and accessible policy documents. The documents were analysed in the tradition of a qualitative content analysis. The government strategy document is now available in English [46]. The content analysis of the programme was validated using an analysis of 
the interpretations in the articles provided by the most-read national newspaper Helsingin Sanomat, but this was not reported in this article. Further, the authors' interpretations were contrasted with the results of a study $[63,64]$ based on the interview data of key political and administrative players in the Finnish government formation process. However, this article does not provide systematic empirical evidence on the phenomena but describes the ways in which language of strategy is applied in government programme.

Author Contributions: Each co-author contributed to the reported research and writing of the paper. The research was co-designed, co-performed and co-analyzed and co-written. All authors read and approved the final manuscript.

Conflicts of Interest: The authors declare no conflict of interest.

\section{References}

1. Clausewitz, C. On War; Folio Soc.: London, UK, 2011.

2. Chandler, A.D. Strategy and Structure: Chapters in the History of the Industrial Enterprise; The MIT Press: Cambridge, MA, USA, 1990.

3. Nutt, P.C.; Backoff, R.W. Strategic Management of Public and Third Sector Organizations: A Handbook for Leaders; Jossey-Bass: San Francisco, CA, USA, 1992.

4. Bryson, J.M. Strategic Planning for Public and Nonprofit Organizations: A Guide to Strengthening and Sustaining Organizational Achievement; Jossey-Bass Publishers: San Francisco, CA, USA, 1995.

5. Koteen, J. Strategic Management in Public and Nonprofit Organizations: Managing Public Concerns in an Era of Limits; Praeger: Westport, CT, USA, 1997.

6. Joyce, P. Strategic Management for the Public Services; Open University Press: Buckingham, UK; Philadelphia, PA, USA, 1999.

7. Rabin, J.; Miller, G.; Hildreth Bartley, W. Handbook of Strategic Management; M. Dekker: New York, NY, USA, 2000.

8. Johnson, G.; Scholes, K. Exploring Public Sector Strategy; Financial Times/Prentice Hall: Harlow, UK; New York, NY, USA, 2001.

9. Mulgan, G. The Art of Public Strategy: Mobilizing Power and Knowledge for the Common Good; Oxford University Press: New York, NY, USA, 2009.

10. Lusk, S.; Birks, N. Rethinking Public Strategy; Palgrave Macmillan: New York, NY, USA, 2014.

11. Lakoff, G. The contemporary theory of metaphor. In Metaphor and Thought; Ortony, A., Ed.; Cambridge University Press: New York, NY, USA, 1993; pp. 202-251.

12. Mintzberg, H. The strategy concept I: Five p's for strategy. Calif. Manag. Rev. 1987, 30, 11-24. [CrossRef]

13. Mintzberg, H. The strategy concept II: Another look at why organizations need strategies. Calif. Manag. Rev. 1987, 30, 25-32. [CrossRef]

14. Mintzberg, H. The Rise and Fall of Strategic Planning: Reconceiving Roles for Planning, Plans, Planners; Free Press and Maxwell Macmillan Canada: New York, NY, USA; Toronto, ON, Canada, 1994.

15. Fombrun, C.J.; Tichy, N.M.; Devanna, M.A. Strategic Human Resource Management; Wiley: New York, NY, USA, 1984.

16. Avolio, B.J.; Yammarino, F.J. Transformational and Charismatic Leadership: The Road Ahead; JAI: Amsterdam, The Netherlands, 2002.

17. Mesterton-Gibbons, M.; Gavrilets, S.; Gravner, J.; Akcay, E. Models of coalition or alliance formation. J. Theor. Biol. 2011, 274, 187-204. [CrossRef] [PubMed]

18. Sanchez, R.; Heene, A. Reinventing strategic management: New theory and practice for competence-based competition. Eur. Manag. J. 1997, 15, 303-317. [CrossRef]

19. O'Donnell, M. Maria Montessori: A Critical Introduction to Key Themes and Debates; Bloomsbury Publishing: London, UK, 2013.

20. Hogwood, B.; Gunn, L. Policy Analysis for the Real World; Oxford University Press: London, UK, 1984.

21. De Vries, M. Understanding Public Administration; Palgrave: London, UK, 2016.

22. Dye, T. Understanding Public Policy; Prentice Hall: Englewood Cliffs, NJ, USA, 1992.

23. Easton, D. A Framework for Policy Analysis; Prentice Hall: Englewood Cliffs, NJ, USA, 1965. 
24. Sabatier, P. Theories of the Policy Process; Westview Press: Boulder, CO, USA, 1999.

25. Howlet, M.; Ramesh, M. Studying Public Policy; Oxford University Press: Toronto, ON, Canada, 2003.

26. Klinj, E.-H.; Koppenjan, J.; Termeer, K. Managing networks in the public sector: A theoretical study of management strategies in policy networks. Public Adm. 1995, 73, 437-454.

27. Oxford Dictionary. Available online: https://en.oxforddictionaries.com/ (accessed on 22 May 2017).

28. Online Thesaurus. Available online: http:/ / www.thesaurus.com/ (accessed on 22 May 2017).

29. Parsons, W. Public Policy. An Introduction to the Theory and Practice of Policy Analysis; Edward Elgar: Cheltenham, UK, 1995.

30. Frederickson, G.; Smith, K.; Larimer, C.; Licari, M. The Public Administration Theory Primer, 3rd ed.; Westview Press: Boulder, CO, USA, 2016.

31. Wilson, W. Study of administration. Polit. Sci. Q. 1887, 2, 197-222. [CrossRef]

32. Raadschelders, J.C.N. Understanding government: Four intellectual traditions in the study of public administration. Public Adm. 2008, 86, 925-949. [CrossRef]

33. Pierre, J. Bureaucracy in the Modern State: An Introduction to Comparative Public Administration; Edward Elgar: Aldershot, UK, 1995.

34. Pollit, C.; Bouckaert, G. Public Management Reform-A Comparative Analysis, 2nd ed.; Oxford University Press: New York, NY, USA, 2004.

35. Boyne, G.A. Public and private management: What's the difference? J. Manag. Stud. 2002, 39, 97-122. [CrossRef]

36. Moore, M. Creating Public Value. Strategic Management in Government; Harvard University Press: Boston, MA, USA, 1995.

37. Bozeman, B.; Johnson, J. The political economy of public values. A case for the public sphere and progressive opportunity. Am. Rev. Public Adm. 2014, 45, 61-85. [CrossRef]

38. Bozeman, B. All Organizations Are Public. Bridging Public and Private Organization Theories; Josey Bass: San Francisco, CA, USA, 1987.

39. Heywood, A. Political Theory_An Introduction; Palgrave Macmillan: New York, NY, USA, 1997.

40. Palonen, K. Politiikka. In Käsitteet liikkeessä. Suomen Poliittisen Kulttuurin Käsitehistoria; Hyvärinen, M., Karumäki, J., Palonen, K., Pulkkinen, T., Stenius, H., Eds.; Vastapaino: Tampere, Finland, 2005; pp. 467-518.

41. Palonen, K. Four times of politics: Policy, polity, politicking and politicization. Alternatives 2003, 28, 171-186. [CrossRef]

42. Lupia, A.; Strom, K. Bargaining, transaction costs, and coalition governance. In Cabinets and Coalition Bargaining, The Democractic Life Cycle in Western Europe; Strom, K., Ed.; Oxford University Press: Oxford, UK, 2010; pp. 51-85.

43. Thelen, K. Varieties of capitalism: Trajectories of liberalization and the new politics of social solidarity. Annu. Rev. Polit. Sci. 2012, 15, 137-159. [CrossRef]

44. Nakashidze, M. Government formation and cabinet types in new democracies: Armenia and Georgia in comparative European perspective. Int. Comp. Jurisprud. 2016, 2, 25-35. [CrossRef]

45. Soskice, D. Macroeconomics and varieties of capitalism. In Beyond Varieties of Capitalism: Conflict, Contradictions, and Complementarities in the European Economy; Hancké, B., Rhodes, M., Thatcher, M., Eds.; Oxford University Press: Oxford, UK, 2007; pp. 88-120.

46. Prime Minister's Office. Finland, A Land of Solutions. Strategic Programme of Prime Minister Juha Sipilä's Government 29 May 2015; Prime Minister's office: Helsinki, Finland, 2015.

47. Lyden, F.J.; Miller, E.G. Public Budgeting: Program Planning and Implementation; Prentice-Hall: Englewood Cliffs, NJ, USA, 1982.

48. Tiili, M. Strategic political steering: Exploring the qualitative change in the role of ministers after NPM reforms. Int. Rev. Adm. Sci. 2007, 73, 81-94. [CrossRef]

49. Mintzberg, H.; Waters, J.A. Of strategies, deliberate and emergent. Strateg. Manag. J. 1985, 6, $257-272$. [CrossRef]

50. Weick, K.E. Sensemaking in Organizations; Sage Publications: Thousand Oaks, CA, USA, 1995.

51. Bass, B.M.; Riggio, R.E. Transformational Leadership; L. Erlbaum Associates: Mahwah, NJ, USA, 2006.

52. Tversky, A.; Kahneman, D. Judgment under uncertainty: Heuristics and biases. Science 1974, 185, $1124-1131$. [CrossRef] [PubMed]

53. Quinn, J.B. Managing strategies incrementally. Omega 1982, 10, 613-627. [CrossRef] 
54. Lindblom, C. The science of "muddling through". Public Adm. Rev. 1959, 19, 79-88. [CrossRef]

55. Cohen, M.D.; March, J.G.; Olsen, J.P. A garbage can model of organizational choice. Adm. Sci. Q. 1972, 17, 1-25. [CrossRef]

56. Ellison, B. Bureaucratic politics as agency competition: A comparative perspective. Int. J. Public Adm. 2006, 29, 1259-1283. [CrossRef]

57. March, J.G.; Olsen, J.P. The new institutionalism: Organizational factors in political life. Am. Polit. Sci. Rev. 1984, 78, 734-749. [CrossRef]

58. Aberbach, J.; Putnam, R.; Rockman, B. Bureaucrats and Politicians in Western Democracies; Harvard University Press: Cambridge, MA, USA, 1981.

59. Lee, K.; Raadschelders, J. Political-administrative relations: Impact of and puzzles in Aberbach, Putnam, and Rockman, 1981. Governance 2008, 21, 419-438. [CrossRef]

60. Mouritzen, P.; Svara, J. Leadership at the Apex: Politicians and Administrators in Western Local Governments. University of Pittsburgh Press: Pittsburgh, PA, USA, 2002.

61. Wilson, J.Q. Bureaucracy: What Government Agencies Do and Why They Do It; Basic Books: New York, NY, USA, 1989.

62. Pressman, J.L.; Wildavsky, A.B. Implementation: How Great Expectations in Washington Are Dashed in Oakland: Or, Why It's Amazing That Federal Programs Work at All, This Being a Saga of the Economic Development Administration as Told by Two Sympathetic Observers Who Seek to Build Morals on a Foundation of Ruined Hopes; University of California Press: Berkeley, CA, USA, 1973.

63. Mykkänen, J. Strateginen Hallitusohjelma ja Hallitusohjelmainstituution Muutos. Poliittisen Osallistumisen Eriytyminen: Eduskuntavaaliutkimus 2015; Grönlund, K., Wass, H., Eds.; Department of Justice: Helsinki, Finland, 2016; pp. 224-246.

64. Mykkänen, J. Strategic Government Program: Overview of the Procedure and its Execution; Talouspolitiikan Arviointineuvosto: Helsinki, Finland, 2016.

(C) 2017 by the authors; licensee MDPI, Basel, Switzerland. This article is an open access article distributed under the terms and conditions of the Creative Commons Attribution (CC BY) license (http:/ / creativecommons.org/licenses/by/4.0/). 